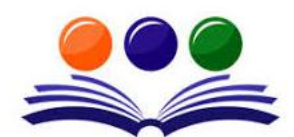

GRAND ACADEMIC PORTAL RESEARCH JOURNALS
A GLOBAL JOURNAL OF SOCIAL SCIENCES

( ISSN - 2581-5830 )

Impact Factor: SJIF - 4.998, IIFS - 4.375

\title{
PERFORMANCE OF COIR INDUSTRY OF INDIA
}

\author{
Reetu Murlidhar Tanwani \\ Research Scholar \\ Gujarat University \\ Mobile: 9925050088 \\ Email: ritzytanwani@gmail.com
}

\begin{abstract}
Coir is the actually waste product of the coconut which is the outer shell of coconut and how this waste is converted into the best products, is the journey of coir industry in India. Coir products are exported to more than 80 countries in the world. India is the largest producer and exporter of the coir and coir products. India contributes $80 \%$ of the world's production of coir. Coir Board is the statutory body which works for the development of coir industry. The study focus is to evaluate the contribution of coir industry in terms of exports, employment, what incentives are offered by the coir board and MSME (Micro, Small and Medium Enterprises) ministry to the coir industry and find out the challenges faced by the coir industry.
\end{abstract}

Keywords: Coir Industry, Coir Board, MSME Ministry, Exports, Employment generation.

\section{INTRODUCTION}

Coir

Coir is a natural fibre which is obtained from the outer part of the coconut. It is used in many ways like making ropes, mats, handicrafts, brushes and many more things are prepared with the coir fibre. It is removed from the coconut husk and then it is cleaned and used to make the products. It looks golden in colour so it is also named as "The Golden Fibre" of India.

Coir Products

Coir Fibre

Coir Yarn

Ropes

Different Coir mats

Different coir matting

Tiles

Coir Rugs

Belts

Non-woven products

Coir Geo-textiles

Coir Pith

Garden articles

Other products

Coir Industry Facts

The coir industry is based in Kerala, Alleppey is the main centre for its production and Kerala alone produces $60 \%$ of world's coir.

The industry employs 7.34 lakh workers which are mostly rural and backward poor class.

Both men and women are actively involved in the production processes of coir and $80 \%$ of the workers are women.

There is huge demand of coir products in the international market because coir is very eco-friendly fibre.

Every year lacs of metric tonnes of coir is produced in India.

Other coconut producing states which are involved in the industry are Tamilnadu, Karnataka, Andhra Pradesh, Orrisa, West Bengal, Maharashtra, Assam and Tripura.

\section{LITERATURE REVIEW}

(Vinayagamoorthi, 2017) The author has focused on the exports contribution of the coir fibre and coir products, different schemes and programmes for the development of the coir Industry. The research paper has also highlighted the advantages and challenges of the coir industry in India.

(Poornimadevi, 2017) The study focuses on the growth and development of the coir industry in the Coimbatore and highlights the major problems faced by the coir industries. The development is depend on the coir board, 


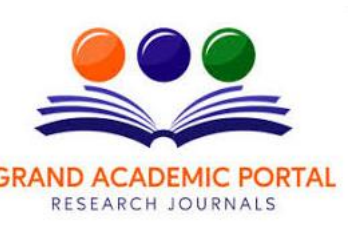

\section{GAP GYAN \\ A GLOBAL JOURNAL OF SOCIAL SCIENCES \\ ( ISSN - 2581-5830 ) \\ Impact Factor: SJIF - 4.998, IIFS - 4.375}

\section{DATA ANALYSIS AND DATA DISCUSSION}

Role of Coir Board and MSME in developing the coir industry

Every year MSME Ministry provides the funds to the coir board for its various activities,

Budgetary Support by MSME

\begin{tabular}{|l|l|l|}
\hline Year & Funds given- plan & Funds given- non plan \\
\hline $2014-15$ & 38.58 & 26.60 \\
\hline $2015-16$ & 31.55 & 23.73 \\
\hline $2016-17$ & 35.04 & 35.70 \\
\hline $2017-18$ & 58.89 & - \\
\hline $2018-19$ & 81.93 & - \\
\hline $2019-20$ & 64.43 & - \\
\hline
\end{tabular}

Schemes for Coir Industry

CVY-Coir Vikas Yojana

For the growth and development of coir industry major scheme implemented is coir vikas yojana which is focused to develop the coir industry and there are five programmes which are small schemes under CVY, these schemes and programmes are as under,

Science and Technology

This is based on the research and development activities of the coir sector to bring new technologies, modern technologies etc. for this there are two research centres 1. Central coir research institute Alleppey, Kerala 2. Central institute of coir technology Bengaluru, Karnataka. These two work for the advancement of coir industry and conducts various workshops, seminars for the applications of R\&D efforts.

Skill upgradation and Mahila coir Yojana

The aim of these two programmes is to develop the skills in the workers and provide training to the workers. Various training institutes are associated with the industry and conducts many training programmes. Under mahila coir yojana women are given employment, skill training and financial assistance to encourage the women in the coir industry.

Export Market Promotion

MSME organizes International buyer seller meet programmes and international fairs in which coir industry units are guided and encouraged for the exports. Various kinds of incentives and promotion is given to boost the exports. It also encourage the small exporters to register for the coir exports.

Domestic Market Promotion

At national level also there are 30 showrooms and sales board for marketing coir goods in the whole country and encourage the public to buy the coir products.

Welfare of the workers

Workers of the coir industry are given the many incentives like insurance schemes are given which covers the accidental insurance schemes etc.

\section{COIR UDYAMI YOJANA- CUY}

This is credit linked subsidy scheme which is for the set-up of coir unit and assistance is provided by the MSME. The one who wants to setup or register for new unit under the coir industry are given the benefits of this scheme.

Export data of Coir

\begin{tabular}{|l|l|l|}
\hline year & Quantity in metric ton & In lakh Rupees \\
\hline $2014-2015$ & 626666 & 163033.77 \\
\hline $2015-2016$ & 752020 & 190142.52 \\
\hline $2016-2017$ & 957045 & 228164.82 \\
\hline $2017-2018$ & 1016564 & 253227.84 \\
\hline $2018-2019$ & 964046 & 272804.59 \\
\hline $2019-2020$ up to December 2020 & 764000 & 210000.00 \\
\hline
\end{tabular}

Source: MSME Annual Reports

Top 5 Countries which import coir and its products from India

\begin{tabular}{|l|l|l|}
\hline No. & Country & Percentage of exports \% \\
\hline 1. & China & 36.75 \\
\hline 2. & USA & 12.68 \\
\hline 3. & Netherlands & 10.06 \\
\hline 4. & South Korea & 7.80 \\
\hline
\end{tabular}




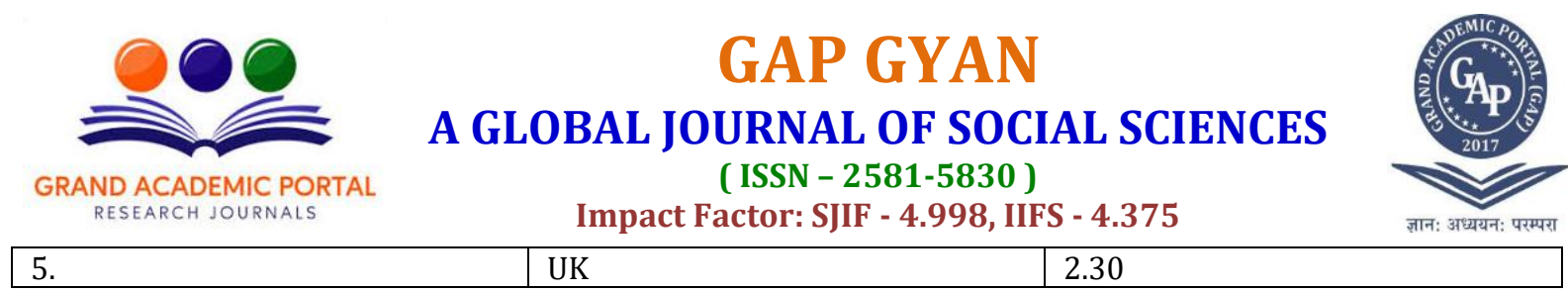

Source: MSME Annual Reports

Coir Production

\begin{tabular}{|l|l|}
\hline Year & Coir fibre production in metric ton \\
\hline $2014-15$ & 542000 \\
\hline $2015-16$ & 549300 \\
\hline $2016-17$ & 556900 \\
\hline $2017-18$ & 559400 \\
\hline $2018-19$ & 749600 \\
\hline $2019-2020$ up to December 2020 & 567000 \\
\hline
\end{tabular}

Source: MSME Annual Reports

There is increase in the quantity of coir production every year at a constant rate and value has also increased gradually, in the year 2018-19 it is 272804.59 coir exported of 964046 metric tons. Coir industry is moving ahead with increasing its exports in the international market. Major three countries which import coir includes China, USA and Netherlands.

Till December 2019 the production of coir fibre was 567000 metric ton. The production also goes steadily increasing. According to the data in the year 2018-19 there was highest production with 749600 metric ton. From the year 2014 to 2018 the coir production was stable and there was no major jump however, in the year 2018-19 the major jump is seen in the production of coir which is 749600 .

Employment Generation - State wise data

\begin{tabular}{|l|l|l|l|l|l|l|}
\hline State & $2014-15$ & $2015-16$ & $2016-17$ & $2017-18$ & $2018-19$ & $2019-20$ \\
\hline Kerala & 470788 & 472100 & 472961 & 474590 & 475077 & 475080 \\
\hline Tamil Nadu & 125937 & 127420 & 129803 & 130862 & 132443 & 132445 \\
\hline Karnataka & 30338 & 30440 & 30872 & 31159 & 31365 & 31365 \\
\hline $\begin{array}{l}\text { Andhra } \\
\text { Pradesh }\end{array}$ & 52946 & 53825 & 54477 & 54670 & 55455 & 55455 \\
\hline Odisha & 17210 & 17535 & 17760 & 18135 & 18421 & 18420 \\
\hline Other & 20542 & 20650 & 20876 & 20965 & 21031 & 21180 \\
\hline
\end{tabular}

Source: MSME Annual Reports

Kerala and Tamil Nadu are the centres of the development of coir and major units works there so higher employment is seen in the both states. Highest employment is seen in the Kerala in the year 2019-20 which is 475080. In other states like Karnataka, Odisha and Andhra Pradesh it is comparatively less.

\section{CHALLENGES OF THE COIR INDUSTRY}

\section{Competition}

The coir industry is facing tough competition against the other natural fibres and synthetic fibres so use of coir is replaced with the other cheap fibres. Another countries which produce coir like Sri Lanka Vietnam are also giving the competition to India.

Workers Safety

Workers safety is another big challenge for the industry as coir industry is worker and labour oriented industry and workers health is badly impacted in working with the coir fibre so necessary steps should be taken for the health safety of the workers.

Shortage of Raw materials

China and other few countries import only coir fibre and prepare the products in their countries thus in India there is shortage of coir fibre raw materials and unable to meet the demand of the other coir products.

Migration of workers

There is migration of workers seen in the previous years that workers leave the coir industry and shift to another industries so reasons of the migration can be low salaries, health of the workers etc.

\section{CONCLUSION}

Coir Industry plays very crucial role in the development of the country. It generates the employment opportunities for the rural and poor workers and help them in the training. The coir industry has the major share in the exports of the country. There is huge demand of the coir products domestically as well as internationally. Coir Board and Ministry of MSME works well for the development of the industry. The production of the coir is also increasing day by day so with the proper management of the raw material coir industry can get more success. Coir industry is totally based on the workers so extra care should be taken 
